Article

\title{
Eco-Efficiency and Human Capital Efficiency: Example of Small- and Medium-Sized Family Farms in Selected European Countries
}

\author{
Jan Polcyn (1)
}

check for updates

Citation: Polcyn, J. Eco-Efficiency and Human Capital Efficiency: Example of Small- and Medium-Sized Family Farms in Selected European Countries. Sustainability 2021, 13, 6846. https://doi.org/10.3390/ su13126846

Academic Editor: Michael S. Carolan

Received: 1 April 2021

Accepted: 14 June 2021

Published: 17 June 2021

Publisher's Note: MDPI stays neutral with regard to jurisdictional claims in published maps and institutional affiliations.

Copyright: (C) 2021 by the author. Licensee MDPI, Basel, Switzerland. This article is an open access article distributed under the terms and conditions of the Creative Commons Attribution (CC BY) license (https:/ / creativecommons.org/licenses/by/ $4.0 /)$.
Department of Economics, Stanislaw Staszic State University of Applied Sciences, 64-920 Piła, Poland; jan.polcyn@puss.pila.pl

\begin{abstract}
Small- and medium-sized family farms are places to live and sources of income for about half of the population. The aim of this analysis was to determine the relationship between ecoefficiency and human capital efficiency on small- and medium-sized family farms. The analysis was carried out using an economic measure (value of agricultural production per work hour calculated per hectare) and two synthetic measures (human capital and environmental measures). The synthetic measures were determined using the TOPSIS-CRITIC method by defining weights for variables used in the measures. The analysis covered five countries: Lithuania (960 farms), Moldavia (532 farms), Poland (696 farms), Romania (872 farms) and Serbia (524 farms). All of these countries are characterised by a high fragmentation of agricultural holdings. The analysis allowed us to formulate the following conclusions: eco-efficiency and human capital efficiency indices increased with area for small- and medium-sized family farms. An increase in the eco-efficiency index with an increase in farm area suggests that the smaller the farm area, the more extensive the agricultural production that was carried out. In addition, an increase in human capital efficiency with an increase in farm area indicates that there was inefficiency in the utilisation of human capital resources on the agricultural farms studied.
\end{abstract}

Keywords: eco-efficiency; human capital efficiency; family farms; TOPSIS-CRITIC; sustainable development

\section{Introduction}

Small farms are most often identified in terms of technological backwardness, low efficiency and poverty [1,2]. It is sometimes suggested that they are an unnecessary element in the agricultural landscape [3]. However, it is important to remember that small farms provide a place to live and work for nearly half of the world's population [4].

Small- and medium-sized family farms are most often considered places for the production of healthy food and reservoirs of biodiversity. The need to protect the environment forces everyone to take rational actions aimed at sustainable development; one measure for such development may be eco-efficiency. It should be understood as a measure of sustainability that directly links environmental impact to economic performance [5]. Ecoefficiency can be applied as a control tool at the production management level to mitigate environmental impact [6].

There is a widespread opinion that large farms are characterised by a low eco-efficiency index. However, this common opinion is not always confirmed by analysis [6]. Certainly, large farms cause strong environmental pressure, but such a phenomenon is not necessarily associated with a low eco-efficiency index. Does this mean that a favourable eco-efficiency index is present in all situations involving small- and medium-sized family farms? Furthermore, it is commonly believed that the level of human capital is correlated with economic productivity and the level of environmental protection [7-9]. If this opinion were to be confirmed in real situations, then farms with higher levels of human capital should be 
characterised by higher productivity, and consequently, higher levels of human capital efficiency. Of course, in discussing this problem, we should distinguish between the theoretical possibilities of increasing production, namely human capital resources, and the practical possibilities associated with the availability of the means of production enabling an increase in productivity. On small- and medium-sized family farms, there may be a high value of human capital without the possibility of use due to limitations in production resources such that there will be no possibility of increasing productivity. We may also imagine a situation where we have at our disposal considerable production capacity, expressed as the area of an agricultural farm, a rich machinery fleet and a low value of human capital, which would not allow for the utilisation of these capacities.

This research was carried out in five European countries characterised by similar political histories and highly fragmented agriculture. This study aimed to answer the following research questions: What is the level of eco-efficiency in small- and mediumsized family farms in the selected European countries? What is the level of human capital efficiency in the investigated farms? What is the relationship between eco-efficiency and human capital efficiency?

Eco-efficiency refers to achieving the desired economic results while creating the least environmental degradation [10]. As one of the many methods of assessing eco-efficiency, the ratio of economic development to environmental pressure is determined by taking into account soil pollution, water pollution, air pollution and biodiversity, as indicated in the calculations [11].

Some studies related to sustainability emphasise the need for trade-offs between environmental, economic and social efficiency [12]. Similar analyses may also focus on determining the indicators of environmental burden, the sustainability of organic production value and the sustainability of farm eco-efficiency [13].

Developed societies are characterised by a high degree of concern for environmental protection, where this issue occupies a very important place in the public dialogue in these societies, as well as management and policy programmes [14]. Human capital is closely related to environmental awareness, and in fact, education (an important component of human capital) has a particularly strong relationship with environmental problems [9]. Human capital can be described in many ways. Here, we provide a definition that captures the most important ideas. Human capital can be understood as the aggregation of activities related to education, health, workplace training and migration that improve productivity in the labour market $[8,15]$. Some authors add innate capabilities to the definition, which are understood as the physical, intellectual and psychological abilities that people are born with [16]. Even though unambiguous definitions of human capital are known, measuring it turns out to be a complicated process due to the different factors used for measurement and the difficulty in expressing these factors numerically. The following are used as determinants of human capital: leadership experience, length of service, work experience in line with the speciality, organisational commitment of employees, IT skills, education, employee skills, attitudes, motivation and international experience $[17,18]$. Despite the broad catalogue of variables, it is not a closed set and the use of further variables depends on the researchers and the compatibility of the variables used with the idea of human capital.

Productivity growth associated with human capital has been observed for a long time, with the benefits of investing in human capital being noted at both the organisational and individual levels [7]. It is often pointed out that a company's performance, especially at the operational level (not subject to inflation) positively influences human capital efficiency [17]. A quantitative increase in human capital increases the productivity of employees and the efficiency of machines and also results in an appropriate approach with customers and translates into the quality of manufactured products [19]. Some studies confirm that the intellectual capital of companies (a component of human capital) has a positive impact on their market value and financial performance; as a result, these relationships allow companies to build durable advantages, especially in emerging economies where different 
levels of technological progress may affect the process of intellectual capital valuation [20]. It should also be assumed that the domain of agriculture is subject to such favourable influences on human capital. Some studies also make reference to organisational social capital, the relationship between organisational costs and human capital. The importance of social capital increases with changes in the nature of the work, the organisational structure of the workplace and competition between organisations [21]. However, it should be noted that not all analysts agree with the statement that human capital plays a positive role [17]. There are well-known research findings indicating that industry-specific capital plays a special role in specific organisations [22]. Industry-specific capital can also refer to agricultural production. This type of specific capital allows decisions to be made that are consistent with the company's unique strategy, organisational context and competitive environment [23].

There are many reports in the academic literature on human capital issues, but few of them address the problem of human capital efficiency itself. We only found reports focusing on the problem of human capital efficiency from a labour market perspective [24] or analyses related to the search for efficiency related to intellectual capital linked to human capital [25].

\section{Materials and Methods}

Small- and medium-sized family farms in Lithuania, Moldova, Poland, Romania and Serbia were analysed. The qualification criteria for this group of farms were the area of the farm (up to $20 \mathrm{ha}$ ), the value of standard production (up to EUR 25,000) and the share of one's own labour involved in agriculture (a minimum of 75\%). The data for the analyses were obtained from a survey conducted in 2019 on a sample of 960 farms in Lithuania, 532 farms in Moldova, 696 farms in Poland, 872 farms in Romania and 524 in Serbia. Thus, the total sample was 3584 farms.

Data were collected through face-to-face interviews by farm advisors or specialised companies. The interview used a structured questionnaire that contained four thematic blocks of questions: economic and social sustainability, environmental sustainability, market links and general farm characteristics. To ensure correct data collection, pilot studies preceded the main research. The pilot studies included several interviews at selected agricultural holdings in order to check the correctness and clarity of the questions included in the questionnaire. As a result of the pilot studies, incomprehensible questions were removed or corrected, and appropriate comments were added to other questions. The economic measure was the value of agricultural production per work hour per hectare. The obtained value of the measure was subjected to zero unitisation according to Formula (1):

$$
\text { stimulant }: z_{i j}=\frac{x_{i j}-\min _{i}\left\{x_{i j}\right\}}{\max _{i}\left\{x_{i k}\right\}-\min _{i}\left\{x_{i j}\right\}},(i=1,2, \ldots, n ; j=1,2, \ldots, k \text {; from } \in[0,1] \text {. }
$$

where $\min _{i}\left\{x_{i j}\right\}$ is the minimum value of function $j, \max _{i}\left\{x_{i k}\right\}$ is the maximum value of function $j$ and $i$ is the object ( $a$ farm in the case under consideration).

The variables used for the synthetic measures of human and environmental capital were subjected to zero unitisation according to Formula (1) for stimulants, whereas for destimulants, Formula (2) was applied:

destimulant $: \mathrm{z}_{\mathrm{ij}}=\frac{\max _{\mathrm{i}}\left\{\mathrm{x}_{\mathrm{ij}}\right\}-\mathrm{x}_{\mathrm{ij}}}{\max _{\mathrm{i}}\left\{\mathrm{x}_{\mathrm{ik}}\right\}-\min _{\mathrm{i}}\left\{\mathrm{x}_{\mathrm{ij}}\right\}},(\mathrm{i}=1,2, \ldots, \mathrm{n} ; \mathrm{j}=1,2, \ldots, \mathrm{k} ;$ from $\in[0,1]$

where $\min _{\mathrm{i}}\left\{\mathrm{x}_{\mathrm{ij}}\right\}$ is the minimum value of function $\mathrm{j}, \max _{\mathrm{i}}\left\{\mathrm{x}_{\mathrm{ik}}\right\}$ is the maximum value of function $j$ and $i$ is the object (a farm in the case under consideration).

The synthetic measure of human capital was determined using the following variables: work experience; education; agricultural qualifications; participation in continuing education by farm owners and their family members; participation in social events by farm owners and their family members; membership in organisations, associations or clubs by farm owners and their family members. People achieve mastery by the age of 
retirement or pre-retirement because at that point they are able to provide professional and social experience. Between the ages of 35 and 55, both women and men reach their highest productivity and make the most significant contribution to social life [26]. The literature concerning changes in the ability to perform work tasks with age indicates that ability increases during the first 10 years of professional life due to general education and learning by doing and reaches a maximum at around 30-35 years of age. It then stabilises until around age 50, at which point it begins to decline. The process of productivity decline is rather slow and strongly depends on both personal and occupational characteristics [27]. There are well-known studies indicating patterns in labour productivity rates in different age groups, starting from a low level of about $20 \%$ in the 15- to 19-year-old group and rising to about $80 \%$ in the 25 - to 55 -year-old group, before falling below $20 \%$ at around age 65 [28].

Based on the above-mentioned literature, assuming that agriculture is a laborious task, it was assumed that labour productivity increases from the age of 20 to 35 , remains stable between the ages of 36 and 50 and then decreases until retirement at the age of 67 (this age was used to determine the lowest indicator). Therefore, the following indicators were used: age up to 25 years, indicator 0.6 ; 26-30 years, 0.8 ; 31-35 years, $0.9 ; 36-50$ years, 1.0 ; $51-55$ years, $0.9 ; 56-60$ years, $0.8 ; 61-65$ years, $0.7 ; 66$ years and over, 0.6 . Each farmer's age was then multiplied by the corresponding indicator.

The synthetic environmental measure was determined using the following variables: $\mathrm{CH}_{4}$ emissions per hectare, $\mathrm{N}$ emissions per hectare, soil organic substance balance in tonnes per hectare, mineral fertiliser consumption in tonnes per hectare, crop protection product expenditure per year per hectare, fuel expenditure per year per hectare and electricity expenditure per year per hectare.

Methane $\left(\mathrm{CH}_{4}\right)$ emissions from enteric fermentation and animal manure were calculated according to the Intergovernmental Panel on Climate Change (IPCC) tier 1 method (IPCC, 2006). Manure from grazing and confined animals was considered to be returned to the pasture system as fertiliser (nutrient cycle) [29].

Gaseous emissions of $\mathrm{N}_{2} \mathrm{O}, \mathrm{NO}, \mathrm{NH}_{3}$ and $\mathrm{CO}_{2}$ from fertiliser applications were modelled based on IPCC tier 1 emission factors (IPCC, 2006). The emission rate of $\mathrm{N}$ to surface water was assumed to be $10 \%$ of the applied $\mathrm{N}$ [29].

Subsequently, weights for the selected variables were determined using the TOPSISCRITIC method (designation of criteria by correlating criteria). In this method, weights are determined based on standard deviations and correlations between variables. A characteristic feature of this method is that relatively higher weights are assigned to characteristics that have a high coefficient of variation and a low correlation with other characteristics [30]. Variable weights were determined according to the following formulas:

$$
w_{j}=\frac{c_{j}}{\sum_{k=1}^{m} c_{k}}, j=1,2, \ldots, m ; c_{j}=s_{j(z)} \sum_{k=1}^{m}\left(1-r_{i j}\right), j=1,2, \ldots, m,
$$

where $c_{j}$ is a measure of the information capacity of feature $j, s_{j(z)}$ is the standard deviation calculated from the normalised values of feature $j$ and $r_{i j}$ is the correlation coefficient between features $\mathrm{j}$ and $\mathrm{k}$.

The next step was to multiply the established normalised values of the variables by the appropriate weighting coefficients. Using the values of the variables after the weighting process, the Euclidean distances of the individual units from the development pattern and anti-pattern were calculated according to the following formulas:

$$
\begin{gathered}
\mathrm{d}_{\mathrm{i}}^{+}=\sqrt{\sum_{\mathrm{j}=1}^{\mathrm{k}}\left(\mathrm{z}_{\mathrm{ij}}^{*}-\mathrm{z}_{\mathrm{ij}}^{+}\right)^{2}-\text { distance from development pattern }} \\
\mathrm{d}_{\mathrm{i}}^{-}=\sqrt{\sum_{\mathrm{j}=1}^{\mathrm{k}}\left(\mathrm{z}_{\mathrm{ij}}^{*}-\mathrm{z}_{\mathrm{ij}}^{-}\right)^{2}}-\text { distance from development antipattern }
\end{gathered}
$$


where $\mathrm{z}_{\mathrm{j}}^{+}=\left(\max \left(\mathrm{z}_{\mathrm{i} 1}^{*}\right), \max \left(\mathrm{z}_{\mathrm{i} 2}^{*}\right), \ldots, \max \left(\mathrm{z}_{\mathrm{ik}}^{*}\right)\right)=\left(\mathrm{z}_{1}^{+}, \mathrm{z}_{2}^{+}, \ldots \mathrm{z}_{\mathrm{i}}^{+}\right)$and $\mathrm{z}_{\mathrm{j}}^{-}=\left(\min \left(\mathrm{z}_{\mathrm{i} 1}^{*}\right)\right.$, $\left.\min \left(\mathrm{z}_{\mathrm{i} 2}^{*}\right), \ldots, \min \left(\mathrm{z}_{\mathrm{ik}}^{*}\right)\right)=\left(\mathrm{z}_{1}^{-}, \mathrm{z}_{2}^{-}, \ldots \mathrm{z}_{\mathrm{i}}^{-}\right)$.

In the next step, the value of the synthetic characteristic q1 was determined according to the following formula:

$$
\mathrm{q}_{\mathrm{i}}=\frac{\mathrm{d}_{\mathrm{i}}^{-}}{\mathrm{d}_{\mathrm{i}}^{+}+\mathrm{d}_{\mathrm{i}}^{-}},(\mathrm{i}=1,2, \ldots, \mathrm{n})
$$

Table 1 presents a list of variables used in the TOPSIS-CRITIC analysis and the weights of the different elements.

Table 1. List of variables used to create the synthetic measures.

\begin{tabular}{|c|c|c|c|}
\hline Name of Synthetic Measure & Name of Variable & $\begin{array}{c}\text { Type of } \\
\text { Variable }\end{array}$ & Weight \\
\hline \multirow{12}{*}{ Human capital } & \multirow{12}{*}{$\begin{array}{c}\text { Professional experience } \\
\text { Education } \\
\text { Agricultural qualification } \\
\text { Participation in continuing education: farm owner } \\
\text { Participation in continuous education: spouse } \\
\text { Participation in continuing education: other adults } \\
\text { Participation in social/cultural events: farm owner } \\
\text { Participation in social/cultural events: spouse } \\
\text { Participation in social/cultural events: other adults } \\
\text { Membership in any organisation, association, club, etc.: farm owner } \\
\text { Membership in any organisation, association, club, etc.: spouse } \\
\text { Membership in any organisation, association, club, etc.: } \\
\text { other adults }\end{array}$} & Stimulant & 0.693 \\
\hline & & Stimulant & 0.082 \\
\hline & & Stimulant & 0.030 \\
\hline & & Stimulant & 0.023 \\
\hline & & Stimulant & 0.017 \\
\hline & & Stimulant & 0.007 \\
\hline & & Stimulant & 0.024 \\
\hline & & Stimulant & 0.028 \\
\hline & & Stimulant & 0.030 \\
\hline & & Stimulant & 0.030 \\
\hline & & Stimulant & 0.025 \\
\hline & & Stimulant & 0.012 \\
\hline \multirow{7}{*}{ Environmental } & $\mathrm{CH}_{4}$ emission per hectare & Destimulant & 0.221 \\
\hline & $\mathrm{N}$ emission per hectare & Destimulant & 0.228 \\
\hline & Soil organic matter balance, tonnes per hectare & Destimulant & 0.130 \\
\hline & Mineral fertiliser consumption, tonnes per hectare & Destimulant & 0.097 \\
\hline & Expenses for plant protection products per year per hectare & Destimulant & 0.096 \\
\hline & Fuel expenses per year per hectare & Destimulant & 0.099 \\
\hline & Electricity expenses per year per hectare & Destimulant & 0.129 \\
\hline
\end{tabular}

Source: Author's own elaboration based on the conducted analyses.

An eco-efficiency analysis makes it possible to compare different solutions by determining the relationships between economic and environmental factors. Measures of eco-efficiency can indicate the level of innovation and also make it possible to assess the environmental impact of technologies used [31]. Based on the above formulations, the eco-efficiency (EE) index was determined according to Formula (7):

$$
\mathrm{EE}=\frac{\text { economic measure }}{\text { environmental measure }}
$$

An analysis of reports in the literature indicates that environmental concern is strongly correlated with human capital [32]. Determining the human capital efficiency (HCE) was motivated by reports on socio-eco-efficiency (SEE) [33]. Although SEE problems seem similar to HCE problems, they are different, as different variables were used to analyse these problems [34]. Socio-eco-efficiency studies have considered working conditions (occupational accidents, fatalities, occupational diseases, potential toxicity, wages and salaries, companies' expenditure on vocational training, strikes and lockouts), data covering the international community (child labour, foreign direct investment and supplies from developing countries), data on future generations (number of interns, business R\&D expenditures and capital investment) and data on local and national communities (workers, worker qualifications, gender equality, integration of people with disabilities, part-time 
workers and family support) $[35,36]$. Taking the abovementioned factors into account, it was decided to introduce a new measure, which was referred to in this study as the human capital efficiency (HCE) index. The HCE index was determined using Formula (8):

$$
\mathrm{HCE}=\frac{\text { economic measure }}{\text { human capital measure }}
$$

\section{Results and Discussion}

The contemporary literature points to small- and medium-sized family farms as special places for creating public goods [37]. An important element when assessing the function of these farms is low pressure on the environment, which is often emphasised [38,39]. Low pressure on the environment is also related to the correlated impact of human capital; among other things, it is commonly emphasised that the higher the farmer's education, the lower the pressure on the environment [40]. The observations made in this publication indicate an increase in the value of the economic measure with an increase in the area of the farm (Table 2). This relation was observed in all analysed countries; although the average area of farms in each class (determined according to the economic measure) varied, we observed a constant tendency of an increased economic measure value with increased farm area. This can partly be explained by the use of economies of scale for production, although small farms usually have a greater opportunity to carry out production requiring higher labour input. Only one exception to the rule was found, which was in the analysis pertaining to Serbia, wherein the class with the highest economic measure value had a farm area smaller than the preceding class (marked with a $C$ in the analyses; (Table 2, Appendix A). However, it should also be noted that, concerning Serbia, we observed a very small differentiation of farm area between the analysed classes since the average area of farms was between 3.93 ha in class A and 4.39 ha in class D. It is also important to pay attention to the construction of the economic measure itself, which expresses only one value, namely, the value of agricultural production per hectare and per working hour. Thus, the observations clearly indicate that the value of agricultural production per hectare and per working hour increased with increased farm area.

Table 2. Characteristics of farms grouped by classes of economic measures.

\begin{tabular}{|c|c|c|c|c|c|c|c|}
\hline \multirow{2}{*}{$\mathbf{K}$} & \multirow{2}{*}{$\mathbf{N}$} & \multirow{2}{*}{$\mathbf{P}$} & \multicolumn{5}{|c|}{ Measures } \\
\hline & & & E & KL & $\mathrm{S}$ & EE & HCE \\
\hline \multicolumn{8}{|c|}{ Lithuania } \\
\hline B & 240 & 8.82 & 0.1112 & 0.804 & 0.0829 & 2.5532 & 0.212 \\
\hline $\mathrm{C}$ & 240 & 12.16 & 0.2033 & 0.7352 & 0.0857 & 4.0938 & 0.3487 \\
\hline $\mathrm{D}$ & 240 & 12.42 & 0.4334 & 0.7132 & 0.0821 & 7.0416 & 0.9399 \\
\hline \multicolumn{8}{|c|}{ Moldavia } \\
\hline $\mathrm{A}$ & 133 & 4.15 & 0.0116 & 0.708 & 0.7892 & 0.0148 & 0.0194 \\
\hline B & 133 & 4.97 & 0.0294 & 0.7115 & 0.7945 & 0.0371 & 0.0508 \\
\hline $\mathrm{C}$ & 133 & 5.27 & 0.0585 & 0.6562 & 0.7845 & 0.0747 & 0.1154 \\
\hline $\mathrm{D}$ & 133 & 6.34 & 0.1966 & 0.6643 & 0.7821 & 0.2524 & 0.4139 \\
\hline \multicolumn{8}{|c|}{ Poland } \\
\hline A & 174 & 12.18 & 0.03 & 0.7975 & 0.7958 & 0.0392 & 0.0586 \\
\hline B & 174 & 13.78 & 0.0512 & 0.8126 & 0.8035 & 0.0649 & 0.0698 \\
\hline $\mathrm{C}$ & 174 & 13.39 & 0.0785 & 0.7798 & 0.8039 & 0.1 & 0.1889 \\
\hline $\mathrm{D}$ & 174 & 16.84 & 0.1872 & 0.7607 & 0.7957 & 0.2425 & 0.3696 \\
\hline \multicolumn{8}{|c|}{ Romania } \\
\hline A & 218 & 1.39 & 0.0563 & 0.7337 & 0.7286 & 0.0775 & 0.1776 \\
\hline B & 218 & 4.06 & 0.0531 & 0.7161 & 0.7414 & 0.0717 & 0.1239 \\
\hline $\mathrm{C}$ & 218 & 8.11 & 0.0698 & 0.7558 & 0.7441 & 0.0939 & 0.1422 \\
\hline $\mathrm{D}$ & 218 & 37.08 & 0.136 & 0.753 & 0.7447 & 0.1826 & 0.2769 \\
\hline
\end{tabular}


Table 2. Cont.

\begin{tabular}{cccccccc}
\hline \multirow{2}{*}{$\mathbf{K}$} & $\mathbf{N}$ & $\mathbf{P}$ & \multicolumn{7}{c}{ Measures } \\
\cline { 4 - 8 } & & \multicolumn{8}{c}{$\mathbf{E}$} & $\mathbf{K L}$ & $\mathbf{S}$ & $\mathbf{E E}$ & HCE \\
\hline \multicolumn{10}{c}{ Serbia } \\
$\mathrm{A}$ & 131 & 3.93 & 0.0074 & 0.6906 & 0.7481 & 0.0099 & 0.0179 \\
$\mathrm{~B}$ & 131 & 3.71 & 0.0146 & 0.708 & 0.7409 & 0.0198 & 0.0231 \\
$\mathrm{C}$ & 131 & 4.5 & 0.0263 & 0.6919 & 0.7419 & 0.0355 & 0.044 \\
$\mathrm{D}$ & 131 & 4.39 & 0.0791 & 0.6701 & 0.7385 & 0.108 & 0.1445 \\
\hline
\end{tabular}

K, class designated by economic measure; $\mathrm{N}$, number of objects in class; $\mathrm{P}$, farm area; E, economic measure; KL, human capital measure; S, environmental measure; EE, eco-efficiency; HCE, human capital efficiency. Source: Author's own elaboration based on the conducted analyses.

Taking into account the above relationship, it is interesting to check the development of eco-efficiency, understood as the relationship between the economic measure and the pressure on the environment, which was expressed in this study as the environmental measure (its construction is discussed in the Materials and Methods section). After analysing this relationship, we found that the eco-efficiency (EE) indicator also increased with increased farm area; this expresses the difference between the analysed classes as determined by the economic measure. Similar relationships were observed in other studies conducted in Poland; these studies show that farms with higher eco-efficiency are characterised by larger farmland area, higher production value and higher economic expenditure per hectare, but at the same time lower expenditure per production unit [41]. The EE differentiation in this study was supported by an assessment of contrasts (Table 3, Appendix A).

Table 3. Contrast assessment.

\begin{tabular}{|c|c|c|c|c|c|c|c|c|c|}
\hline Name & $\mathbf{N}$ & Class & $\begin{array}{c}\text { Mean } \\
\text { Values }\end{array}$ & SS Effect & $\begin{array}{c}\text { Contrast } 1 \\
(1 ; 0 ; 0 ;-1)\end{array}$ & $\begin{array}{c}\text { Contrast } 2 \\
(0 ; 1 ; 0 ;-1)\end{array}$ & $\begin{array}{c}\text { Contrast } 3 \\
(0 ; 0 ; 1 ;-1) \\
\end{array}$ & $\begin{array}{c}\text { Contrast } 4 \\
(1 ;-1 ; 0 ; 0)\end{array}$ & $\begin{array}{r}\text { Contrast } 5 \\
(0 ; 1 ;-1 ; 0)\end{array}$ \\
\hline \multicolumn{10}{|c|}{ Lithuania } \\
\hline $\begin{array}{c}\text { Eco- } \\
\text { Efficiency }\end{array}$ & $\begin{array}{l}240 \\
240 \\
240 \\
240\end{array}$ & $\begin{array}{l}\text { A } \\
B \\
C \\
D\end{array}$ & $\begin{array}{l}0.8219 \\
2.5532 \\
4.0938 \\
7.0416\end{array}$ & 5015.8 & 0.93 & 0.48 & 0.21 & 0.07 & 0.06 \\
\hline $\begin{array}{l}\text { Human } \\
\text { Capital } \\
\text { Efficiency }\end{array}$ & $\begin{array}{l}240 \\
240 \\
240 \\
240\end{array}$ & $\begin{array}{l}\text { A } \\
\text { B } \\
\text { C } \\
\text { D }\end{array}$ & $\begin{array}{l}0.0638 \\
0.2120 \\
0.3487 \\
0.9399\end{array}$ & 106.1 & 0.87 & 0.60 & 0.40 & 0.02 & 0.02 \\
\hline \multicolumn{10}{|c|}{ Moldavia } \\
\hline $\begin{array}{c}\text { Eco- } \\
\text { Efficiency }\end{array}$ & $\begin{array}{l}133 \\
133 \\
133 \\
133 \\
\end{array}$ & $\begin{array}{l}\text { A } \\
\text { B } \\
\text { C } \\
\text { D }\end{array}$ & $\begin{array}{l}0.0148 \\
0.0371 \\
0.0747 \\
0.2524\end{array}$ & 4.651 & 0.81 & 0.66 & 0.45 & 0.01 & 0.02 \\
\hline $\begin{array}{l}\text { Human } \\
\text { Capital } \\
\text { Efficiency }\end{array}$ & $\begin{array}{l}133 \\
133 \\
133 \\
133\end{array}$ & $\begin{array}{l}\text { A } \\
B \\
C \\
D\end{array}$ & $\begin{array}{l}0.0194 \\
0.0508 \\
0.1154 \\
0.4139\end{array}$ & 13.001 & 0.80 & 0.67 & 0.46 & $\mathrm{np}$ & 0.02 \\
\hline & & & & & Poland & & & & \\
\hline $\begin{array}{c}\text { Eco- } \\
\text { Efficiency }\end{array}$ & $\begin{array}{l}174 \\
174 \\
174 \\
174\end{array}$ & $\begin{array}{l}\text { A } \\
B \\
\text { C } \\
\text { D }\end{array}$ & $\begin{array}{l}0.0391 \\
0.0649 \\
0.1000 \\
0.2425\end{array}$ & 4.299 & 0.84 & 0.64 & 0.41 & 0.01 & 0.03 \\
\hline
\end{tabular}


Table 3. Cont.

\begin{tabular}{|c|c|c|c|c|c|c|c|c|c|}
\hline Name & $\mathbf{N}$ & Class & $\begin{array}{l}\text { Mean } \\
\text { Values }\end{array}$ & SS Effect & $\begin{array}{c}\text { Contrast } 1 \\
(1 ; 0 ; 0 ;-1)\end{array}$ & $\begin{array}{c}\text { Contrast } 2 \\
(0 ; 1 ; 0 ;-1)\end{array}$ & $\begin{array}{c}\text { Contrast } 3 \\
(0 ; 0 ; 1 ;-1)\end{array}$ & $\begin{array}{c}\text { Contrast } 4 \\
(1 ;-1 ; 0 ; 0)\end{array}$ & $\begin{array}{l}\text { Contrast } 5 \\
(0 ; 1 ;-1 ; 0)\end{array}$ \\
\hline \multirow{4}{*}{$\begin{array}{c}\text { Human } \\
\text { Capital } \\
\text { Efficiency }\end{array}$} & 174 & A & 0.0586 & \multirow{4}{*}{10.899} & \multirow{4}{*}{0.77} & \multirow{4}{*}{0.72} & \multirow{4}{*}{0.26} & \multirow{4}{*}{$\mathrm{np}$} & \multirow{4}{*}{0.11} \\
\hline & 174 & B & 0.0698 & & & & & & \\
\hline & 174 & $\mathrm{C}$ & 0.1889 & & & & & & \\
\hline & 174 & $\mathrm{D}$ & 0.3696 & & & & & & \\
\hline \multicolumn{10}{|c|}{ Romania } \\
\hline \multirow{4}{*}{$\begin{array}{c}\text { Eco- } \\
\text { Efficiency }\end{array}$} & 218 & A & 0.0775 & \multirow{4}{*}{1.7435} & \multirow{4}{*}{0.69} & \multirow{4}{*}{0.77} & \multirow{4}{*}{0.49} & \multirow{4}{*}{$\mathrm{np}$} & \multirow{4}{*}{0.03} \\
\hline & 218 & B & 0.0717 & & & & & & \\
\hline & 218 & $\mathrm{C}$ & 0.0939 & & & & & & \\
\hline & 218 & $\mathrm{D}$ & 0.1826 & & & & & & \\
\hline \multirow{4}{*}{$\begin{array}{l}\text { Human } \\
\text { Capital } \\
\text { Efficiency }\end{array}$} & 218 & A & 0.1775 & \multirow{4}{*}{3.0469} & \multirow{4}{*}{0.35} & \multirow{4}{*}{0.84} & \multirow{4}{*}{0.65} & \multirow{4}{*}{ np } & \multirow{4}{*}{$\mathrm{np}$} \\
\hline & 218 & B & 0.1239 & & & & & & \\
\hline & 218 & $\mathrm{C}$ & 0.1422 & & & & & & \\
\hline & 218 & $\mathrm{D}$ & 0.2769 & & & & & & \\
\hline \multicolumn{10}{|c|}{ Serbia } \\
\hline \multirow{4}{*}{$\begin{array}{c}\text { Eco- } \\
\text { Efficiency }\end{array}$} & 131 & A & 0.0099 & \multirow{4}{*}{0.7745} & \multirow{4}{*}{0.81} & \multirow{4}{*}{0.66} & \multirow{4}{*}{0.44} & \multirow{4}{*}{ np } & \multirow{4}{*}{0.02} \\
\hline & 131 & B & 0.0198 & & & & & & \\
\hline & 131 & $\mathrm{C}$ & 0.0354 & & & & & & \\
\hline & 131 & $\mathrm{D}$ & 0.1079 & & & & & & \\
\hline \multirow{4}{*}{$\begin{array}{l}\text { Human } \\
\text { Capital } \\
\text { Efficiency }\end{array}$} & 131 & A & 0.0179 & \multirow{4}{*}{1.3773} & \multirow{4}{*}{0.76} & & & & \\
\hline & 131 & B & 0.0230 & & & & & np & $\mathrm{np}$ \\
\hline & 131 & $\mathrm{C}$ & 0.0439 & & & 0.70 & 0.48 & np & nр \\
\hline & 131 & $\mathrm{D}$ & 0.1445 & & & & & & \\
\hline
\end{tabular}

Source: Author's own elaboration based on the analysed data.

We also note that the value of EE increased with the increased farm area. Other studies indicate that $\mathrm{EE}$ increases with increased farmland area, income per farm family member and family size [42]. Reports on the evolution of EE are varied, where some studies show a completely different relationship, that is, EE is found to decrease with increased farm area [43]. In the presented research, the highest difference was found between the value of EE in class $\mathrm{A}$ in relation to class $\mathrm{D}$ (the class with the highest value of the economic measure); interestingly, the same relationship was observed in all analysed countries. This differentiation was supported by the results of the contrast assessment. The differences between classes A, B and C in relation to class D turned out to be statistically significant in each analysed country (Lithuania, Moldavia, Poland, Romania and Serbia). The contrast between class A (lowest economic measure) and class D varied from $93 \%$ of the variation in group averages (Lithuania) to 63\% (Romania). Similar relationships were also found in the data from the other countries: Moldavia, $81 \%$; Poland, $84 \%$; and Serbia, $81 \%$. The variation of group averages between analysed classes can be seen in Table 2 (Appendix A).

When evaluating the contrast between classes $B$ and $D$, we found statistically significant differences in all analysed countries. The highest level of variation between classes B and D was found in the Romanian data (77\%) and the lowest was found in the Lithuanian data (48\%) (Table 3). Further analysis shows an even lower level of variation in EE between classes $C$ and $D$, although the differences are still statistically significant. The highest level of explaining the differences between the classes in question was found in Romania (49\%) and the lowest level between classes C and D was found in Lithuania (21\%) (Table 3). As we note in Table 3, the level of explained variation became lower as we approach the $\mathrm{D}$ (highest) EE class.

There is a common opinion that large-scale farms exert a great deal of pressure on the environment, and consequently, have a low EE [43]. In the described research, we noticed the reverse tendency, which was also confirmed in the literature, i.e., EE increased with increased farm area $[10,41]$. However, it should be taken into account that the small- and 
medium-sized family farms that were analysed generally have extensive management, in contrast to large-scale farms, which have intensive management and thus create stronger environmental pressure [44]. Some researchers pointed out that not only small- and medium-sized family farms, as in this study, but also farms with strong economic power are characterised by increased eco-efficiency, but this does not mean that these farms exert less absolute pressure on the environment [45].

There are scientific reports indicating that farmers' ages and family sizes have a positive impact on EE, both of which can be considered components of human capital [46]. Furthermore, there are studies indicating the broad importance of human capital for agriculture, including its impact on EE [47]. In view of the abovementioned results, the next value analysed was human capital efficiency (HCE). The rationale for analysing this value was based on literature reports indicating the impact of human capital even on GDP if the analysis is conducted on a macroeconomic scale [48]. There are also analyses indicating the influence of human capital on EE, especially through its close relationship with eco-innovativeness [49]. This makes human capital even more crucial for small- and medium-sized family farms [50]. Thus, analyses analogous to those already discussed and related to EE were conducted.

The highest level of explained group variation between class A HCEs was found in the data from Lithuania $(90 \%)$ in relation to class D of this size. The lowest degree of explained variability in class $\mathrm{A}$ in relation to class $\mathrm{D}$ was found in the data from Romania (31\%). It can be assumed that, in general, there are similar relationships as with EE, that is, the level of explained variability decreased in successive classes (B and C) approaching class D HCEs (the class with the highest value of the economic measure). The only exception was the data from Romania, where it was found that the explained variability between classes B and D significantly exceeded the level of variability between classes A and D (Table 3). Similar relationships to EE, relative to HCE, indicated that a large reservoir of human capital was found on the smallest farms managed by either elderly people or people with their main sources of income outside agriculture, probably often lacking the motivation to increase the farm size. With the same potential of human capital, efficiency therefore increased with increased farm area since each area of a small farm could be served by human capital from the small farm (excluding farmers with physical limitations due to age and health conditions). The potential of human capital on small farms is also probably not reached due to limitations related to the implementation of innovative solutions to improve the economic measure of the farms.

\section{Conclusions}

The analyses carried out in five European countries covering small- and medium-sized family farms allowed us to conclude that eco-efficiency increased with increased farm area, and it should be assumed that the increase in EE had a limited value, after which, it decreased. This suggestion can be substantiated by literature reports on the significant environmental pressure caused by large-scale farms [44].

The common belief that small and medium-sized farms produce healthy food using limited amounts of plant protection products and fertilizers is not confirmed by the ecoefficiency index. This points to the need for the continuous popularization of production methods allowing to maintain the desired level of EE.

It was also found that HCE increased with EE, which can be explained by the accumulation of human capital on small farms, which greatly exceeded the capacity to use it, resulting in low HCE on small farms and a gradual increase on larger farms (Figure 1). 
Lithuania
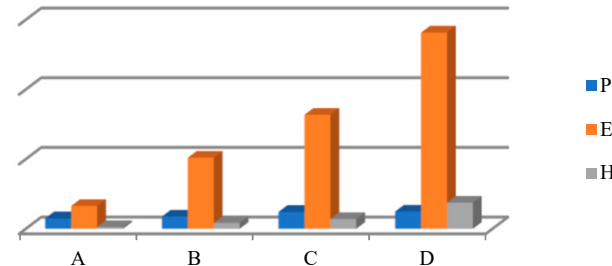

- $\mathrm{EE}$

$-\mathrm{HCE}$

Moldavia

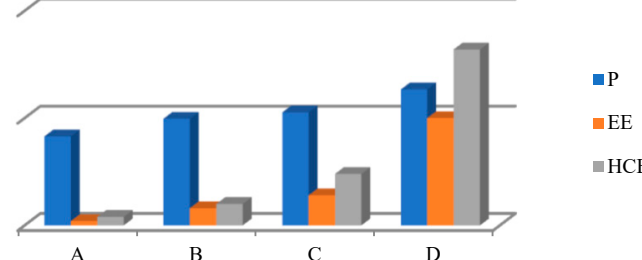

Poland

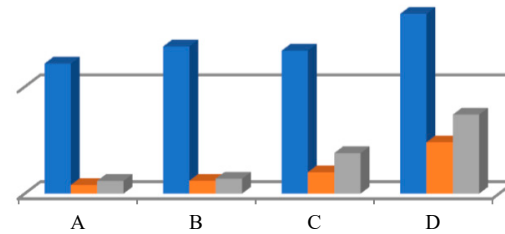

$\square$

EE

$\square \mathrm{HCE}$

Romania

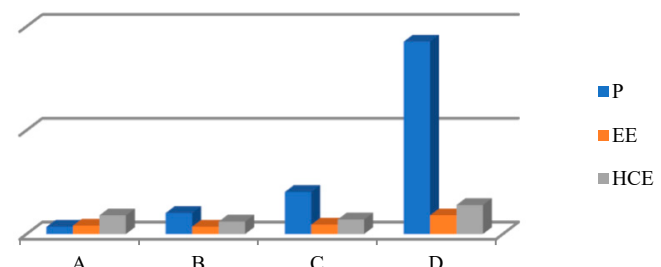

EE

Serbia

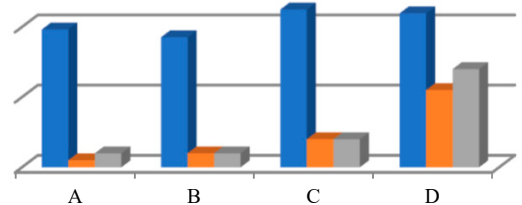

$\because \mathrm{P}$

EE

- HCE

Figure 1. Relation of farm area to eco-efficiency and human capital efficiency. P, area; EE, ecoefficiency; HCE, human capital efficiency. Source: own elaboration based on analysed data.

The conducted analyses indicate that the low efficiency of HCE indicates the unused resources of human capital in the analyzed rural areas. This may indicate that the analyzed agricultural activity in rural areas is only an additional activity of the population living in these areas. In such a situation, it is difficult to imagine an increase in HCE, since, in fact, the human capital, which is represented by the inhabitants of rural areas and used to determine the HCE, is likely to be used outside the of the analyzed agricultural activity in rural areas. In view of the above, it should be noted that the full effectiveness of the HCE should be analyzed together with the non-agricultural activities of rural residents. Certainly, the profile of education included in the construction of the synthetic measure of human capital requires a broader analysis, which should allow, in the longer term, to modify the content of education related to the care for the environment. It should be stated at this stage that the level of responsibility for the environment certainly increases with the level of education.

The low value of EE on small farms also confirmed the rather extensive nature of agricultural production due to farmers' treating these farms as an additional activity, not 
oriented towards commodity production. Moreover, considering the fact that owners of small farms often work off-farm, this should be associated with above-average education for small farms, which contributed to a higher value of the human capital index.

The conducted research implies the necessity to focus on further research on small farms because the processes taking place in them within the analyzed three dimensions of sustainability are slightly different than in the entire population of farms.

The conducted research also has limitations resulting from the method of construction of synthetic measures. In subsequent studies, a set of components of the social dimension should be considered [51].

The original contribution from the conducted research are the tendencies related to the transition between the following classes of farm area and the associated eco-efficiency (EE) and human capital efficiency (HCE).

Funding: This research was funded by the Polish National Agency for Academic Exchange under a program of the International Academic Partnership, agreement no. PPI/APM/2018/1/00011/U/001, and by the National Science Centre in Poland, grant no. 2016/21/B/HS4/00653.

Data Availability Statement: The data presented in this study are available on request from the author.

Conflicts of Interest: The author declares no conflict of interest.

\section{Appendix A}

Table A1. Tests of Significance.

\begin{tabular}{|c|c|c|c|c|c|c|}
\hline \multirow{2}{*}{ Effect } & \multicolumn{6}{|c|}{$\begin{array}{c}\text { Multivariate Tests of Significance, Sigma-Restricted Parameterisation and } \\
\text { Effective Hypothesis Decomposition }\end{array}$} \\
\hline & Test & Value & $\mathbf{F}$ & Effect df & Error df & $p$ \\
\hline \multicolumn{7}{|c|}{ Lithuania } \\
\hline \multirow{4}{*}{ Intercept } & Wilks & 0.03197 & 7215.209 & 4 & 953 & 0 \\
\hline & Pillai's & 0.96803 & 7215.209 & 4 & 953 & 0 \\
\hline & Hotelling's & 30.28419 & 7215.209 & 4 & 953 & 0 \\
\hline & Roy's & 30.28419 & 7215.209 & 4 & 953 & 0 \\
\hline \multirow{4}{*}{$\begin{array}{l}\text { Class-Economic } \\
\text { Measure }\end{array}$} & Wilks & 0.44485 & 75.272 & 12 & 2521.693 & 0 \\
\hline & Pillai's & 0.57154 & 56.19 & 12 & 2865 & 0 \\
\hline & Hotelling's & 1.2113 & 96.063 & 12 & 2855 & 0 \\
\hline & Roy's & 1.18056 & 281.859 & 4 & 955 & 0 \\
\hline \multicolumn{7}{|c|}{ Moldavia } \\
\hline \multirow{4}{*}{ Intercept } & Wilks & 0.0015 & $87,392.7$ & 4 & 525 & 0 \\
\hline & Pillai's & 0.9985 & $87,392.7$ & 4 & 525 & 0 \\
\hline & Hotelling's & 665.8491 & $87,392.7$ & 4 & 525 & 0 \\
\hline & Roy's & 665.8491 & $87,392.7$ & 4 & 525 & 0 \\
\hline \multirow{4}{*}{$\begin{array}{l}\text { Class-Economic } \\
\text { Measure }\end{array}$} & Wilks & 0.4659 & 38.75 & 12 & 1389.311 & 0 \\
\hline & Pillai's & 0.5445 & 29.22 & 12 & 1581 & 0 \\
\hline & Hotelling's & 1.1243 & 49.06 & 12 & 1571 & 0 \\
\hline & Roy's & 1.1043 & 145.49 & 4 & 527 & 0 \\
\hline \multicolumn{7}{|c|}{ Poland } \\
\hline \multirow{4}{*}{ Intercept } & Wilks & 0.01241 & $13,703.89$ & 4 & 689 & 0 \\
\hline & Pillai's & 0.98759 & $13,703.89$ & 4 & 689 & 0 \\
\hline & Hotelling's & 79.55813 & $13,703.89$ & 4 & 689 & 0 \\
\hline & Roy's & 79.55813 & $13,703.89$ & 4 & 689 & 0 \\
\hline \multirow{4}{*}{$\begin{array}{l}\text { Class-Economic } \\
\text { Measure }\end{array}$} & Wilks & 0.55019 & 38.5 & 12 & 1823.214 & 0 \\
\hline & Pillai's & 0.45182 & 30.63 & 12 & 2073 & 0 \\
\hline & Hotelling's & 0.81391 & 46.64 & 12 & 2063 & 0 \\
\hline & Roy's & 0.80941 & 139.83 & 4 & 691 & 0 \\
\hline
\end{tabular}


Table A1. Cont.

\begin{tabular}{|c|c|c|c|c|c|c|}
\hline \multirow{2}{*}{ Effect } & \multicolumn{6}{|c|}{$\begin{array}{c}\text { Multivariate Tests of Significance, Sigma-Restricted Parameterisation and } \\
\text { Effective Hypothesis Decomposition }\end{array}$} \\
\hline & Test & Value & $\mathbf{F}$ & Effect df & Error df & $p$ \\
\hline \multicolumn{7}{|c|}{ Romania } \\
\hline \multirow{4}{*}{ Intercept } & Wilks & 0.001 & 255,497 & 4 & 865 & 0 \\
\hline & Pillai's & 0.999 & 255,497 & 4 & 865 & 0 \\
\hline & Hotelling's & 1181.489 & 255,497 & 4 & 865 & 0 \\
\hline & Roy's & 1181.489 & 255,497 & 4 & 865 & 0 \\
\hline \multirow{4}{*}{$\begin{array}{l}\text { Class-Economic } \\
\text { Measure }\end{array}$} & Wilks & 0.788 & 17.9 & 12 & 2288.866 & 0 \\
\hline & Pillai's & 0.221 & 17.2 & 12 & 2601 & 0 \\
\hline & Hotelling's & 0.257 & 18.5 & 12 & 2591 & 0 \\
\hline & Roy's & 0.199 & 43.1 & 4 & 867 & 0 \\
\hline \multicolumn{7}{|c|}{ Serbia } \\
\hline \multirow{4}{*}{ Intercept } & Wilks & 0.0024 & $53,456.87$ & 4 & 517 & 0 \\
\hline & Pillai's & 0.9976 & $53,456.87$ & 4 & 517 & 0 \\
\hline & Hotelling's & 413.5928 & $53,456.87$ & 4 & 517 & 0 \\
\hline & Roy's & 413.5928 & $53,456.87$ & 4 & 517 & 0 \\
\hline \multirow{4}{*}{$\begin{array}{l}\text { Class-Economic } \\
\text { Measure }\end{array}$} & Wilks & 0.7117 & 15.64 & 12 & 1368.145 & 0 \\
\hline & Pillai's & 0.2904 & 13.91 & 12 & 1557 & 0 \\
\hline & Hotelling's & 0.4022 & 17.28 & 12 & 1547 & 0 \\
\hline & Roy's & 0.3948 & 51.22 & 4 & 519 & 0 \\
\hline
\end{tabular}

Source: Author's own elaboration based on analysed data.

Table A2. Tukey's HSD Test for Dependent Variables of Eco-Efficiency.

\begin{tabular}{|c|c|c|c|c|}
\hline \multicolumn{5}{|c|}{ Approximate Probabilities for Post Hoc Test Error: $\mathrm{MS}=7.7283, \mathrm{df}=956.00$} \\
\hline Class & A & $\mathrm{B}$ & $\mathrm{C}$ & $\mathrm{D}$ \\
\hline \multicolumn{5}{|c|}{ Lithuania } \\
\hline A & & 0.000008 & 0.000008 & 0.000008 \\
\hline $\mathrm{B}$ & 0.000008 & & 0.000008 & 0.000008 \\
\hline $\mathrm{C}$ & 0.000008 & 0.000008 & & 0.000008 \\
\hline $\mathrm{D}$ & 0.000008 & 0.000008 & 0.000008 & \\
\hline \multicolumn{5}{|c|}{ Moldavia } \\
\hline \multicolumn{5}{|c|}{ Approximate Probabilities for Post Hoc Test Error: $\mathrm{MS}=0.00800, \mathrm{df}=528.00$} \\
\hline A & & 0.175025 & 0.000008 & 0.000008 \\
\hline B & 0.175025 & & 0.003461 & 0.000008 \\
\hline $\mathrm{C}$ & 0.000008 & 0.003461 & & 0.000008 \\
\hline $\mathrm{D}$ & 0.000008 & 0.000008 & 0.000008 & \\
\hline \multicolumn{5}{|c|}{ Poland } \\
\hline \multicolumn{5}{|c|}{ Approximate Probabilities for Post Hoc Test Error: MS $=0.00831, \mathrm{df}=692.00$} \\
\hline $\mathrm{A}$ & & 0.042334 & 0.000008 & 0.000008 \\
\hline B & 0.042334 & & 0.001839 & 0.000008 \\
\hline $\mathrm{C}$ & 0.000008 & 0.001839 & & 0.000008 \\
\hline $\mathrm{D}$ & 0.000008 & 0.000008 & 0.000008 & \\
\hline \multicolumn{5}{|c|}{ Romania } \\
\hline \multicolumn{5}{|c|}{ Approximate Probabilities for Post Hoc Test Error: MS $=0.01336, \mathrm{df}=868.00$} \\
\hline A & & 0.953136 & 0.449550 & 0.000008 \\
\hline $\mathrm{B}$ & 0.953136 & & 0.186084 & 0.000008 \\
\hline $\mathrm{C}$ & 0.449550 & 0.186084 & & 0.000008 \\
\hline $\mathrm{D}$ & 0.000008 & 0.000008 & 0.000008 & \\
\hline
\end{tabular}


Table A2. Cont.

\begin{tabular}{ccccc}
\hline \multicolumn{4}{c}{ Serbia } \\
\hline & Approximate Probabilities for Post Hoc Test Error: $\mathrm{MS}=0.00384, \mathrm{df}=520.00$ \\
\hline A & & 0.568489 & 0.004685 & 0.170860 \\
B & 0.568489 & 0.170860 & 0.000008 \\
C & 0.004685 & 0.000008 & 0.000008 \\
D & 0.000008 & 0.00008 & \\
\hline
\end{tabular}

Source: Author's own elaboration based on analysed data.

Table A3. Tukey's HSD Test for Dependent Variables of Human Capital Efficiency.

\begin{tabular}{|c|c|c|c|c|}
\hline \multicolumn{5}{|c|}{ Approximate Probabilities for Post Hoc Test Error: MS $=0.37664, \mathrm{df}=956.00$} \\
\hline Class & A & B & C & $\mathrm{D}$ \\
\hline \multicolumn{5}{|c|}{ Lithuania } \\
\hline A & & 0.040667 & 0.000010 & 0.000008 \\
\hline $\mathrm{B}$ & 0.040667 & & 0.069839 & 0.000008 \\
\hline $\mathrm{C}$ & 0.000010 & 0.069839 & & 0.000008 \\
\hline $\mathrm{D}$ & 0.000008 & 0.000008 & 0.000008 & \\
\hline \multicolumn{5}{|c|}{ Moldavia } \\
\hline \multicolumn{5}{|c|}{ Approximate Probabilities for Post Hoc Test Error: MS $=0.05969, \mathrm{df}=528.00$} \\
\hline A & & 0.721033 & 0.007419 & 0.000008 \\
\hline $\mathrm{B}$ & 0.721033 & & 0.135821 & 0.000008 \\
\hline $\mathrm{C}$ & 0.007419 & 0.135821 & & 0.000008 \\
\hline $\mathrm{D}$ & 0.000008 & 0.000008 & 0.000008 & \\
\hline \multicolumn{5}{|c|}{ Poland } \\
\hline \multicolumn{5}{|c|}{ Approximate Probabilities for Post Hoc Test Error: MS $=0.19308, \mathrm{df}=692.00$} \\
\hline A & & 0.995328 & 0.029125 & 0.000008 \\
\hline B & 0.995328 & & 0.055737 & 0.000008 \\
\hline $\mathrm{C}$ & 0.029125 & 0.055737 & & 0.000739 \\
\hline $\mathrm{D}$ & 0.000008 & 0.000008 & 0.000739 & \\
\hline \multicolumn{5}{|c|}{ Romania } \\
\hline \multicolumn{5}{|c|}{ Approximate Probabilities for Post Hoc Test Error: $\mathrm{MS}=0.23331, \mathrm{df}=868.00$} \\
\hline A & & 0.652231 & 0.870734 & 0.138152 \\
\hline B & 0.652231 & & 0.978958 & 0.005210 \\
\hline $\mathrm{C}$ & 0.870734 & 0.978958 & & 0.018855 \\
\hline $\mathrm{D}$ & 0.138152 & 0.005210 & 0.018855 & \\
\hline \multicolumn{5}{|c|}{ Serbia } \\
\hline \multicolumn{5}{|c|}{ Approximate Probabilities for Post Hoc Test Error: MS $=0.01240, \mathrm{df}=520.00$} \\
\hline A & & 0.982202 & 0.231287 & 0.000008 \\
\hline B & 0.982202 & & 0.426294 & 0.000008 \\
\hline $\mathrm{C}$ & 0.231287 & 0.426294 & & 0.000008 \\
\hline $\mathrm{D}$ & 0.000008 & 0.000008 & 0.000008 & \\
\hline
\end{tabular}

Source: Author's own elaboration based on analysed data.

\section{References}

1. Kostov, P.; Lingard, J. Subsistence agriculture in transition economies: Its roles and determinants. J. Agric. Econ. 2004, 55, 565-579. [CrossRef]

2. Mathijs, E.; Noev, N. Subsistence farming in Central and Eastern Europe-Empirical evidence from Albania, Bulgaria, Hungary, and Romania. East. Eur. Econ. 2004, 42, 72-89. [CrossRef]

3. Davidova, S.; Fredriksson, L.; Bailey, A. Subsistence and semi-subsistence farming in selected EU new member states. Agric. Econ. 2009, 40, 733-744. [CrossRef]

4. Wiggins, S.; Kirsten, J.; Llambi, L. The Future of Small Farms. World Dev. 2010, 38, 1341-1348. [CrossRef] 
5. Pari, L.; Suardi, A.; Forleo, M.B.; Coaloa, D.; Palmieri, N. Environmental Impacts and Economic Performance of Major Oil Crops in Italy. In Proceedings of the 26th European Biomass Conference: Setting the Course for a Biobased Economy, Copenhagen, Denmark, 14-18 May 2018; pp. 1444-1449.

6. Gancone, A.; Pubule, J.; Rosa, M.; Blumberga, D. Evaluation of agriculture eco-efficiency in Latvia. In Proceedings of the International Scientific Conference-Environmental and Climate Technologies (Conect 2017), Riga, Latvia, 10-12 May 2017; Volume 128, pp. 309-315. [CrossRef]

7. Becker, B.E.; Huselid, M.A. Strategic human resource management: Where do we go from here? J. Manag. 2006, 32, 898-925. [CrossRef]

8. $\quad$ Schultz, T.W. Inwestment in Human Capital; The Free Press: New York, NY, USA, 1976.

9. Odonkor, S.T.; Adom, P.K. Environment and health nexus in Ghana: A study on perceived relationship and willingness-toparticipate (WTP) in environmental policy design. Urban Clim. 2020, 34, 12. [CrossRef]

10. Stępień, S.; Czyżewski, B.; Sapa, A.; Borychowski, M.; Poczta, W.; Poczta-Wajda, A. Eco-efficiency of small-scale farming in Poland and its institutional drivers. J. Clean. Prod. 2021, 279, 123721. [CrossRef]

11. Matuszczak, A.; Kryszak, L.; Czyzewski, B.; Lopatka, A. Environment and political economics: Left-wing liberalism or conservative leftism-Which is better for eco-efficiency? Evidence from Poland. Sci. Total Environ. 2020, 743, 140779. [CrossRef]

12. Czyżewski, B.; Guth, M. Impact of Policy and Factor Intensity on Sustainable Value of European Agriculture: Exploring Trade-Offs of Environmental, Economic and Social Efficiency at the Regional Level. Agriculture 2021, 11, 78. [CrossRef]

13. Czyżewski, B.; Matuszczak, A.; Muntean, A. Approaching environmental sustainability of agriculture: Environmental burden, eco-efficiency or eco-effectiveness. Agric. Econ. Zemed. Ekon. 2019, 65, 299-306. [CrossRef]

14. Dimopoulos, P.; Kokkoris, I.P. Protection and Management of Species, Habitats, Ecosystems and Landscapes: Current Trends and Global Needs. Forests 2020, 11, 1244. [CrossRef]

15. Becker, G.S. Human Capital; NBER: New York, NY, USA, 1975.

16. Laroche, M.; Merette, M.; Ruggeri, G.C. On the concept and dimensions of human capital in a knowledge-based economy context. Can. Public Policy Anal. Polit. 1999, 25, 87-100. [CrossRef]

17. Crook, T.R.; Todd, S.Y.; Combs, J.G.; Woehr, D.J.; Ketchen, D.J. Does Human Capital Matter? A Meta-Analysis of the Relationship Between Human Capital and Firm Performance. J. Appl. Psychol. 2011, 96, 443-456. [CrossRef]

18. Kwilinski, A.; Vyshnevskyi, O.; Dzwigol, H. Digitalization of the EU Economies and People at Risk of Poverty or Social Exclusion. J. Risk Financ. Manag. 2020, 13, 142. [CrossRef]

19. Youndt, M.A.; Snell, S.A.; Dean, J.W.; Lepak, D.P. Human resource management, manufacturing strategy, and firm performance. Acad. Manag. J. 1996, 39, 836-866. [CrossRef]

20. Chen, M.C.; Cheng, S.J.; Hwang, Y.C. An empirical investigation of the relationship between intellectual capital and firms' market value and financial performance. J. Intellect. Cap. 2005, 6, 159-167. [CrossRef]

21. Dess, G.G.; Shaw, J.D. Voluntary turnover, social capital, and organizational performance. Acad. Manag. Rev. 2001, 26, 446-456. [CrossRef]

22. Grant, R.M. Prospering in dynamically-competitive environments: Organizational capability as knowledge integration. Organ. Sci. 1996, 7, 375-387. [CrossRef]

23. Kor, Y.Y.; Mahoney, J.T. How dynamics, management, and governance of resource deployments influence firm-level performance. Strateg. Manag. J. 2005, 26, 489-496. [CrossRef]

24. Kwon, H. Economic Theories of Low-Wage Work. J. Hum. Behav. Soc. Environ. 2014, 24, 61-70. [CrossRef]

25. Yoon, G.W.; Ryu, S.H. A Study of the Human Capital Efficiency in the Korean Online Game Business using Non-parametric Analysis Model (DEA). J. Korea Game Soc. 2009, 9, 81-94.

26. Mandrzejewska-Smól, I. Wiek i doświadczenie jako atrybuty działalności zawodowej. In Praca Człowieka w XXI Wieku: Konteksty —Wyzwania-Zagrożenia; Gerlach, R., Ed.; Wydawnictwo Uniwersytetu Kazimierza Wielkiego: Bydgoszcz, Poland, 2008; (Age and experience as attributes of professional activity. In Human Work in XXI Century: Contexts—Challenges—Threats; Gerlach, R., Ed.; Publishing House of the Kazimierz Wielki University: Bydgoszcz, Poland, 2008).

27. Göbel, C.; Zwick, T. Which personnel measures are effective in increasing productivity of old workers? Are personnel measures effective in increasing productivity of old workers? Labour Econ. 2013, 22, 80-93. [CrossRef]

28. Ruzik-Sierdzińska, A.; Lis, M.; Potoczna, M.; Belloni, M.; Villosio, C. Age and Productivity. Human Capital Accumulation and Depreciation; CASE Network Reports, No. 114/2013; CASE-Center for Social and Economic Research: Warszawa, Poland, 2012.

29. Jeffery, M.L.; Guetschow, J.; Gieseke, R.; Gebel, R. PRIMAP-crf: UNFCCC CRF data in IPCC 2006 categories. Earth Syst. Sci. Data 2018, 10, 1427-1438. [CrossRef]

30. Borychowski, M.; Stepien, S.; Polcyn, J.; Tosovic-Stevanovic, A.; Calovic, D.; Lalic, G.; Zuza, M. Socio-Economic Determinants of Small Family Farms' Resilience in Selected Central and Eastern European Countries. Sustainability 2020, 12, 10362. [CrossRef]

31. Wojdalski, J.; Niżnikowski, R. Energia, woda i środowisko w produkcji mleczarskiej —Zarys problematyki. Przegląd Hod. 2019, 87, 24-29, (Energy, water and environment in dairy production-An outline of issues. Anim. Prod. Rev. 2019, 87, 24-29).

32. Zhang, Y.L.; Xiao, X.; Cao, R.B.; Zheng, C.H.; Guo, Y.R.; Gong, W.X.; Wei, Z.C. How important is community participation to eco-environmental conservation in protected areas? From the perspective of predicting locals' pro-environmental behaviours. Sci. Total Environ. 2020, 739, 10. [CrossRef] 
33. Charmondusit, K.; Phatarachaisakul, S.; Prasertpong, P. The quantitative eco-efficiency measurement for small and medium enterprise: A case study of wooden toy industry. Clean Technol. Environ. Policy 2014, 16, 935-945. [CrossRef]

34. Anwar, S.N.B.M.; Alvarado, V.; Hsu, S.-C. A socio-eco-efficiency analysis of water and wastewater treatment processes for refugee communities in Jordan. Resour. Conserv. Recycl. 2021, 164, 105196. [CrossRef]

35. Spitzeck, H.; Chapman, S. Creating shared value as a differentiation strategy-The example of BASF in Brazil. Corp. Gov. Int. J. Bus. Soc. 2012, 12, 499-510. [CrossRef]

36. Kharazishvili, Y.; Kwilinski, A.; Grishnova, O.; Dzwigol, H. Social Safety of Society for Developing Countries to Meet Sustainable Development Standards: Indicators, Level, Strategic Benchmarks (with Calculations Based on the Case Study of Ukraine). Sustainability 2020, 12, 8953. [CrossRef]

37. Matuszczak, A. Ewolucja Kwestii Agrarnej a Środowiskowe Dobra Publiczne; Instytut Ekonomiki Rolnictwa i Gospodarki Żywnościowej-Państwowy Instytut Badawczy: Warszawa, Poland, 2020; (Evolution of the Agrarian Issue and Environmental Public Goods; Institute of Agricultural and Food Economics-National Research Institute: Warsaw, Poland, 2020).

38. Staniszewski, J. Attempting to Measure Sustainable Intensification of Agriculture in Countries of The European Union. J. Environ. Prot. Ecol. 2018, 19, 949-957.

39. Polakova, J.; Soukup, J. Results of Implementing Less-Favoured Area Subsidies in the 2014-2020 Time Frame: Are the Measures of Environmental Concern Complementary? Sustainability 2020, 12, 10534. [CrossRef]

40. Jin, T.Y.; Li, M. Does education increase pro-environmental willingness to pay? Evidence from Chinese household survey. J. Clean Prod. 2020, 275, 9. [CrossRef]

41. Golas, M.; Sulewski, P.; Was, A.; Kloczko-Gajewska, A.; Pogodzinska, K. On the Way to Sustainable Agriculture-Eco-Efficiency of Polish Commercial Farms. Agriculture 2020, 10, 438. [CrossRef]

42. You, H.Y.; Zhang, X.L. Eco-Efficiency of Intensive Agricultural Production and Its Influencing Factors in China: An Application of DEA-Tobit Analysis. Discret. Dyn. Nat. Soc. 2016, 14. [CrossRef]

43. Cheng, C.Y.; Ren, J.M.; Wang, R.S.; Liu, F. Eco-efficiency assessment of farming activity in China. Nat. Resour. Sustain. Dev. 2012, 361-363, 1776. [CrossRef]

44. Van Grinsven, H.J.M.; Van Eerdt, M.M.; Westhoek, H.; Kruitwagen, S. Benchmarking Eco-Efficiency and Footprints of Dutch Agriculture in European Context and Implications for Policies for Climate and Environment. Front. Sustain. Food Syst. $2019,3,17$. [CrossRef]

45. Grzelak, A. Accumulation of assets in farms covered by the FADN farm accountancy system in Poland-the economic and eco-efficiency context. Manag. Pol. 2019, 23, 281-294. [CrossRef]

46. Canan, S.; Ceyhan, V. The link between production efficiency and opportunity cost of protecting environment in TR83 region, Turkey. Environ. Sci. Pollut. Res. 2020, 27, 35112-35125. [CrossRef]

47. Czyzewski, B.; Sapa, A.; Kulyk, P. Human Capital and Eco-Contractual Governance in Small Farms in Poland: Simultaneous Confirmatory Factor Analysis with Ordinal Variables. Agriculture 2021, 11, 46. [CrossRef]

48. Woessmann, L. Educational production in Europe. Econ. Policy 2005, 20, 445-504. [CrossRef]

49. Dudek, M.; Wrzaszcz, W. On the Way to Eco-Innovations in Agriculture: Concepts, Implementation and Effects at National and Local Level. The Case of Poland. Sustainability 2020, 12, 4839. [CrossRef]

50. Adeniyi, D.A.; Dinbabo, M.F. Efficiency, food security and differentiation in small-scale irrigation agriculture: Evidence from North West Nigeria. Cogent Soc. Sci. 2020, 6. [CrossRef]

51. Repar, N.; Jan, P.; Dux, D.; Nemecek, T.; Doluschitz, R. Implementing farm-level environmental sustainability in environmental performance indicators: A combined global-local approach. J. Clean. Prod. 2017, 140, 692-704. [CrossRef] 